\title{
Sata vuotta suomalaista valtio-oppia
}

\section{ERKKI BERNDTSON}

\section{VALTIO-OPIN SYNTY SUOMESSA}

Politiikan tutkimuksella akateemisena oppiaineena on pitkät perinteet Suomessa. Perustamisvuodet ovat aina tulkinnallisia, mutta yleisesti on hyväksytty näkemys, että suomalaisen valtioopin institutionaalinen historia alkaa vuodesta 1921, kun Helsingin yliopistoon perustettiin yleisen valtio-opin oppituoli.

Tosin jo vuonna 1640 perustetussa vanhassa Turun akatemiassa oli historian ja politiikan professuuri, jonka ensimmäinen haltija oli Michael Olai Wexionius. Nykynäkökulmasta katsoen oppituolin voi katsoa kuitenkin edustaneen lähinnä käytännöllistä filosofiaa.

Helsingissä opetus alkoi vuonna 1924, kun ensimmäiseksi yleisen valtio-opin professoriksi oli valittu Karl Robert Brotherus. Sitä ennen jo vuonna 1922 oppiaineessa hyväksyttiin ensimmäinen väitöskirja, Yrjö Ruudun tutkimus "Kansakunta".

Itsenäistymisen jälkeen myös uuteen Åbo Akademi yliopistoon oli perustettu valtio-opin oppituoli jo vuonna 1918, mutta virkaan valittu ruotsalainen professori Gunnar Rexius kuoli ennen virkaan astumistaan ja oppituoli herätettiin henkiin vasta vuonna 1938, jolloin sitä alkoi hoitaa Sven Lindman. Hänet valittiin virkaan pysyvästi vuonna 1942.

Myös Svenska Handelshögskolan sai professuurin "historiassa ja valtio-opissa" vuonna 1934. Oppituolin ensimmäinen professori Bruno Lesch oli kuitenkin enemmän historioitsija kuin valtio-oppinut. Oppiaine alkoi painottua enemmän valtio-oppiin, kun siihen valittiin professoriksi Lolo Krusius-Ahrenberg vuonna 1948. Valitettavasti oppituoli lakkautettiin vuonna 2005.

Valtio-opin kehitystä Suomessa vahvisti vuonna 1935 perustettu Valtiotieteellinen yhdistys. Se on vanhin eurooppalainen yhdistys tieteenalalla. Keskeistä osaa yhdistyksen perustamisessa näytteli Yrjö Ruutu.

\section{VALTIO-OPIN KEHITYS SUOMESSA TOISEN MAAILMANSODAN JÄLKEEN}

Valtio-oppi tieteenalana alkoi kasvaa Suomessa toisen maailmansodan jälkeen. Ensimmäinen uusi valtio-opin professuuri perustettiin Yhteiskunnalliseen korkeakouluun Helsingissä vuonna 1945 ja virkaan valittiin seuraavana vuonna Jussi Teljo. Korkeakoulu muutti vuonna 1960 Tampereelle ja vuonna 1966 siitä tuli Tampereen yliopisto.

Muissa yliopistoissa seurattiin pian perässä. Turun yliopistoon valtio-opin oppiaine perustettiin vuonna 1961 ja ensimmäiseksi oppiaineen professoriksi valittiin Jaakko Nousiainen. Jyväskylän yliopistossa valtio-opin opetus alkoi osana yhteiskuntatieteitä, kun niitä opettamaan perustettiin apulaisprofessuuri vuonna 1962. Ensimmäinen varsinainen valtio-opin apulais- 
professuuri perustettiin vuonna 1973. Ensimmäiseksi tieteenalan varsinaiseksi professoriksi valittiin vuonna 1993 Kari Palonen.

Lapin yliopistossa politiikan tutkimus alkoi kansainvälisten suhteiden oppiaineena vuonna 1991. Vuonna 2003 valtio-opin opetus laajeni perustamalla kansainvälisten suhteiden rinnalle erillinen valtio-opin oppiaine. Yhdessä ne muodostavat politiikkatieteiden oppiaineen.

Valtio-opin ruotsinkielinen opetus on myös vahvistunut. Helsingin yliopiston valtiotieteelliseen tiedekuntaan liitettiin aiemmin itsenäinen Svenska Social- och Kommunalhögskolan vuonna 1994. Korkeakouluun oli vuonna 1982 perustettu paikallishallinnon apulaisprofessuuri, mikä muuttui myöhemmin "valtio-opin ja hallinnon" (statskunskap med förvaltning) professuuriksi. Lisäksi Åbo Akademissa valtio-oppi on laajentunut Turun ulkopuolelle, kun vuonna 1974 Vaasaan perustettiin yliopiston sivutoimipiste ja vuonna 1984 "valtio-opin ja joukkotiedotuksen" oppiaine (statskunskap med masskommunikation).

Kirjoitus on julkaistu alun perin Valtiotieteellisen yhdistyksen kotisivuilla osana valtio-opin satavuotisjuhlavuotta käsittelevää kirjoitussarjaa.

\section{KIRJOITTAJATIEDOT}

\section{ERKKI BERNDTSON}

VTL, vapaa tutkija

Yleisen valtio-opin lehtori (eläkkeellä)

erkki.berndtson@gmail.com 